\title{
"Prove All Things: Hold Fast That Which Is Good": Deaccessioning and Research Libraries
}

A

rav menumasary comments and dis. claimers. First, this paper represents work in progress on a subject that admits few absolutes and about which, historically at least, there is much to be learned and many lessons to be gleaned.

Secondly, it should be understood that I am not speaking ex cathedra or ex bibliotheca for the New York Public Library, but am presenting my personal views of the subject. In a few places I will depart from policies recently established by the library's board of trustees, but we can all agree that in this field there is plenty of room for honest disagreement.

Thirdly, I have approached the problem as a librarian, not as a scholar, collector, dealer, donor, lawyer, trustee, or paper recycler. I hope that my perspective will be clear and only prejudiced by the needs of research libraries.

Finally, this paper is dedicated to the memory of Sir Thomas Bodley. Difficult a benefactor as he may have been to his first librarian, refusing at one point to allow Thomas James to marry, he discovered or encountered in the early 1600 s most of the problems of growing research libraries, including deaccessioning. I commend to you his life, his surviving writings, his sound counsel, and his example.

In searching for a title for this talk, I dredged from my memory recollection of a book by a famous Brown scholar, Rosalie Co-

David H. Stam is the Andrew W. Mellon director of the Research Libraries of the New York Public Library. His article is a revised version of the keynote address presented at the Deaccession Symposium held at Brown University on June 11-12, 1981, and supported by grants from the National Endowment for the Humanities and the Research Libraries Group. lie, Paradoxia Epidemica. That seemed appropriate since the topic of deaccessioning is fraught with paradoxes, oxymorons, and subjectivism.

Equally appropriate might have been Sir Thomas Browne's Pseudodoxia Epidemica: or Enquiries into very many received tenents and commonly presumed truths (1646). Along those lines I've chosen instead a text from 1 Thessalonians, chapter 5 , verse 21-22: "Prove all things: hold fast that which is good. Abstain from all appearance of evil." Conservative a stance as that may betray, it does summarize very well the essence of a sound deaccession policy, namely, to examine carefully all aspects of disposal decisions on a case-by-case basis, to keep your essential purposes and mission in mind in deciding what to retain and what to discard, and finally, keeping it on the up and up, free of conflicts of interest, lies and evasions, and other forms of evil, apparenit or otherwise. For some, the preceding verse 17 , might also prove helpful: "Pray without ceasing."

Without troubling at the outset to define the term (perhaps the best thing that could emerge from this conference would be a better term), I would like first to share a few reflections on the nature of the problem, then to provide a taxonomy of deaccessions, to examine the factors that might be involved in making deaccession decisions, and finally to suggest some institutional policy guidelines intended to benefit and protect the institution while avoiding the pitfalls as much as possible.

Obviously, deaccessioning is a hot topic at the moment. The rare-book market is high and institutions are broke. Discussions and rumors throughout the country of mergers of major (and often duplicative) collections and of the sale of entire rare-book rooms inti- 
mate, on the one hand, that some institutions are ready to hatch their golden eggs and, on the other hand, that an avalanche of materials may hit the market over a relatively short period, cutting the market down to size and making alloy of many of those nest eggs. The topic is hardly a new one, but publicity over the last decade to the Metropolitan Museum's "Grand Acquisitors," to Boston's George and Martha, to Carnegie-Mellon's coin collection, to Johns Hopkins' Garrett Collection, to Worcester's Stubbs drawings, to threatened sales of art at Warwick Castle and Dulwiche College, to Yale's Brasher Doubloon, and, most recently, to Brown's sale of illuminated manuscripts have whetted the appetites of some institutions and honed the consciences of many individuals. The issue often exposes institutional vulnerability and brings out the more mordant sensibilities of the critic. At the height of the Gilbert Stuart controversy, for example, ARTnews sympathetically cited the suggestion of a Boston reporter that the solution was for Boston to keep the paintings and sell the Athenaeum. You also may remember a 1973 article in Art in America entitled "Should Hoving Be DeAccessioned?"1 Those examples are mildly satiric compared to the more invidious innuendo of the rare-book salons intended to exalt the true bibliophile and debunk the bibliophilistine.

How can we analyze objectively the nature of a problem that brings out so many hostile emotions on either side, for whatever sincere and/or self-serving purposes? Part of the problem, I suspect, is a widespread cultural belief in the sacredness of the book, the printed word, and even the written word. We're told it was there in the beginning, and, by God, no one ought to desecrate it, and that includes moving a book from one library to another. Every librarian has been burned by that issue, having discarded or transferred something that someone else thinks valuable. But there is an opposite tradition to the cult of the book and it can appear in the deaccessioning argument. How many of you believe that the burning(s) of the Alexandrian Library were a good thing? You may be surprised to learn that among those who did or would have were Seneca, Caesar, the Caliph Omar, Edward Gibbon, Louis LeRoy, Sir Thomas Browne, Jean Jacques Rousseau, David
Hume, Jacob Burckhardt, Friedrich Nietzsche, George Bernard Shaw, and, I suppose by extension, the late Marshall McLuhan. ${ }^{2}$

Browne, for example, has this passage in Religio Medici:

I HAVE heard some with deepe sighs lament the lost lines of Cicero; others with as many groanes deplore the combustion of the Library of Alexandria; for my owne part, I thinke there be too many in the world, and could with patience behold the urne and ashes of the Vatican, could I with a few others recover the perished leaves of Solomon... . [Would] that there were a generall Synod; not to unite the incompatible differences of Religion, but for the benefit of learning, to reduce it as it lay at first in a few and solid Authours; and to condemne to the fire those swarms and millions of Rhapsodies, begotten onely to distract and abuse the weaker judgements of Scholars, and to maintaine the Trade and Mystery of Typographers. ${ }^{3}$

More caustic is Shaw's dialogue in Act II of Caesar and Cleopatra where Alexandria is under siege and burning:

Theodotus [on the steps, with uplifted arms]. Horror unspeakable! Woe, alas! Help!

Rufio. What now?

Caesar [frowning]. Who is slain?

Theodotus [running down the hall between them]. The fire has spread from your ships. The first of the seven wonders of the world perishes. The library of Alexandria is in flames... .

Caesar. Is that all?

Theodotus [unable to believe his senses]. All! Caesar: will you go down to posterity as a barbarous soldier too ignorant to know the value of books?

Caesar. Theodotus: I am an author myself; and I tell you it is better that the Egyptians should live their lives than dream them away with the help of books.

Theodotus [kneeling, with genuine literary emotion: the passion of the pedant]. Caesar: once in ten generations of men, the world gains an immortal book.

Caesar [inflexible]. If it did not flatter mankind, the common executioner would burn it.

Theodotus. Without history, death would lay you beside your meanest soldier.

Caesar. Death will do that in any case. I ask no better grave.

Theodotus. What is burning there is the memory of mankind.

Caesar. A shameful memory. Let it burn.

Theodotus [wildly]. Will you destroy the past?

Caesar. Ay, and build the future with its ruins.

In our debate this side of the argument can 
appear in the pragmatic question of why we should keep all that junk, or in Caesar's argument that it's better to live lives than dream them away with books. When the British Museum in 1933 acquired the Codex Sinaiticus Petropolitanis from the Russian government for $£ 100,000$, there were loud protests about spending that much money when there were one million unemployed in England. The extent of such arguments today should not be underestimated.

In addition to the cult of the book, there is also the question of the transience of immortality. Sir Thomas Bodley has fared well in this respect (despite some changes in his policy regarding duplicates), but there is a deepseated fear that bequests violated will cease to perpetuate the memory of the donor. An institution that fails to honor either the legal requirements or the less formal wishes of its donors can easily alienate other potential benefactors. We shall return to that problem later.

Shortly after the British Museum opened its new quarters in 1759 , Thomas Gray, the elegist, wrote to James Brown of the quiet solitude of the reading room:

. . . when I call it peaceful, you are to understand it only of us Visiters, for the Society itself, Trustees, \& all, are up in arms, like the Fellows of a College, the Keepers have broke off all intercourse with one another, \& only lower a silent defiance, as they pass by . . . moreover, the trustees lay out $500 £$ a year more than their income; so you may expect, all the books \& the crocodiles will soon be put up to auction. the University (we hope) will buy.

August 8, $1759^{5}$

History is studded with disastrous dispersals, usually emerging from disastrous circumstances (e.g., the dispersal of Charles the First's art collections, the seizures of the $\mathrm{Na}$ poleonic wars, the sales by the Soviet government after the revolution, the plunder and destruction of entire libraries in the Second World War). One of the disastrous circumstances is financial and the problem is not new, prevalent as it is today.

The argument for sale is posed in this way: How can a library justify or afford the retention of valuable assets when it cannot keep its doors open sufficient hours, balance its budgets, preserve what it already has, and keep its collections growing in the most useful way? A $\$ 1,000,000$ volume consulted once a year costs at least $\$ 60,000$ per use. Couldn't that be put to better institutional purposes? Compelling as that argument may be to some, it negates the very idea of a research library. Wilmarth Lewis addressed the intellectual side of this argument in his Collector's Progress:

It doesn't bother me in the least that in the future many of my books will stand unopened for many years on end. Counting the number of times a book is used as a criterion of value is to reduce a research library and its purposes to absurdity; on that basis the most valuable books in it are its telephone books. Every great library has tens of thousands of books that may not be called for once in a decade. Paradoxically, it is these books that make it great. ${ }^{\circ}$

There are several other issues that make deaccessioning problematical: the speculative nature of the market; the subjectivity of many of the judgments involved; the real threat to people's livelihoods or reputations; the effects of fluctuations in scholarly fashions; the balancing of the needs of growth over and against the needs of preserving and caring for what we already have; the possible removal of material from public or local access; and the many ethical questions involved $^{7}-$ all of these amply demonstrate the difficulties involved in deaccessioning.

Before turning to the factors that should be considered in a comprehensive deaccession policy, a few brief words should be said about various types of deaccessioning. I've come across the following nine types and would welcome suggestions of others:

1. The Deaccession Nugatory - throwing away the useless. An absolute necessity in all libraries, no matter how difficult the judgments involved.

2. The Deaccession Rapacious-loss by plunder and looting (cf. Napoleon and Hitler).

3. The Deaccession Inadvertent-loss by mistake. Probably the best known example is the Bodleian First Folio.

4. The Deaccession Censorious - e.g., the great deprivations first of the English Reformation and the subsequent loss of many reformed works in the Marian reign.

5. The Deaccession Mendatious, Covert or Mysterious - no successful examples, by definition, but we all know of such cases. 6. The Deaccession Incendiary-a
method recommended by Caliph Omar, 


\section{8 / College \& Research Libraries • January 1982}

David Hume, and a number of School Boards in the USA.

7. The Deaccession Extraneous-weeding. Not recommended for large research libraries.

8. The Deaccession Duplicative-weeding of second copies, often by sale.

9. The Deaccession Remunerative-the sale of assets for money or exchange.

With respect to the last two types, and especially the deaccession by sale, transfer, or exchange of valuable books and other assets for other institutional purposes: What must be taken into account in deciding to pursue this course?

Since the most obvious and least problematical source of revenues through sales is by disposal of valuable duplicates, I will deal at some length with that issue and then much more briefly with many of the other questions involved in deaccession decisions. Duplication in itself is not a bad thing and, in fact, is an essential component of any university library collection policy, designed to provide sufficient copies of much-used books for student use. "Two are better than one," says the author of Ecclesiastes (chapter 4, verse 9) in a passage that seems more relevant to resource sharing than to the vain accumulation of treasures. On the other hand, the same author later claims that "money answereth all things" (Eccles. 10:19) and the sale of duplicates for some institutions could be the answer.

The trustees of NYPL recently had an extensive debate over the phrase "undoubted duplicate," one side arguing that important variants could be lost without careful comparison of copies to assure true duplication, the other that too strict a definition would prevent any significant action. Falconer Madan's paper, "Duplicity of Duplicates," read to the Bibliographical Society in 1911, took the conservative approach: "I do not advocate the collection of duplicates (that way madness lies), but I do advocate ... the greatest care in getting rid of them when you think you have them."

Madan's point was that there are very few true duplicates of pre-1800 hand-printed books. Fredson Bowers, in a 1966 essay, extends the argument to machine-printed books and implies the need to follow Madan's way to madness:
If a library is to serve advanced bibliographical scholarship applied to machine-printed books, it must collect broadly what appear to be duplicates of the "first edition," else the evidence will never be assembled for the detection of concealed printings that cannot be distinguished by the conventional evidence of binding-variation or of so-called "points," but by the expert use of the Hinman Collator. In addition, it must forsake the collectorfostered cult of the first edition in favor of the assembly of every ascertainable later printing or edition-I assert-even down to the twenty-fifth printing in paperback form. ${ }^{9}$

Quite apart from the fact that research libraries have other constituencies to serve besides that of advanced bibliographical scholarship, one wonders how many libraries he thought should duplicate this effort of duplication.

In a less sophisticated bibliographical age, Sir Thomas Bodley took a more practical approach to what he called "double books," though his view of "superfluous books" as described in his letters and in the original statutes of the Bodleian Library should and has been challenged. Bodley was concerned that all books given to the library be in fit condition and even expected donors to defray the cost of binding or repair. When this wasn't possible, he advised his librarian, "It will be requisite to take bookes, that we haue already, whereby those charges may the better be defraied" (i.e., the cost of binding could be covered by the sale of duplicate books). ${ }^{10}$

A short time later in France, Gabriel Naudé's Advice on Establishing a Library (Avis pour dresser une bibliothèque), first published twenty-five years later, also alluded to the subject of duplication. It calls for alphabetical author catalogues in any library, "first that duplication may be avoided, and second, that gaps may be detected." 11

For quite other reasons, Robert H. Taylor in a paper read to the Bibliographical Society of America in 1954, argued "the importance of not having multiple copies." ${ }^{2}$ His concern was the increasing flow of good books into institutional libraries and thus their disappearance from the market and the thwarting of the collector. I'm sure some of you have observed in the memoirs and biographies of rare-book dealers how materials acquired as unwanted duplicates of libraries were often sold to other libraries as the most significant 
of variants. I do not disparage the role of dealer or collector in discovering what went unobserved by the librarian, either for ignorance, lack of interest, or the press of other important business. Nonetheless, one cannot totally suppress the sense of disingenuousness in some of the sales techniques. ${ }^{13}$

Parenthetically, I should point out that the New York Public Library has a rather checkered history of duplicate sales, a history that begins before the formal consolidation of the Astor and the Lenox libraries in $\mathbf{1 8 9 5}$. We have at the library two bound volumes of priced auction sale catalogues involving duplicates resulting from the merger. They make fascinating browsing and deserve a thorough study by someone more knowledgeable than I. The first sale, on April 29, 1895, at Bangs Auction House, consisted of duplicates from the Lenox Library and brought a net credit to the trustees of $\$ 5,068.43$. Those trustees included such luminaries as Samuel Avery, Nicholas Murray Butler, Charles Scribner, and John S. Kennedy, president.

Hindsight isn't much help, but I wish we still had some of the books that passed in those early sales, if only for investment purposes. Audubon's Folio Birds brought $\$ 192.50$; the Quadrupeds $\$ 151.50$; Baskerville's Terence, \$1.00; George Bancroft's own copy of his six-volume History of the United States, 65 cents; and 118 volumes uniformly bound of the Quarterly Review (1809-1865), 15 cents. The sales continued through 1920, twenty in all, with the majority occurring before the move of the two libraries into the new building in 1911 .

H. P. Kraus notes in his autobiography that he was able to buy from the library 12,000 to 15,000 duplicate titles from the Wilberforce Eames Collection, bequeathed to the library in 1937 , for $\$ 1,000$ : “This gave me the start of the reference library I sorely needed and also established me as a dealer in "books about books.' "14 I doubt that such a sale would be approved today. The tradition of duplicate sales, however, is not dead and the library intends, for example, to sell a number of music "duplicates" at auction this fall. I'm sure we can expect to win some and lose some in that speculative enterprise.

Without having solved the problem of what a duplicate actually is or which kinds are unnecessary to a research library, let me turn to the many other factors that must be taken into account in making deaccession decisions.

First and foremost must be the question of what your institution is attempting to do and whether the continued retention of certain materials, whether duplicate or not, is in keeping with that mission. Naturally, a library must be protected against the whims and foibles of capricious changes while being flexible enough to change to accommodate new needs. Irreparable damage can be done by either rigid inflexibility or excessive pliability.

Equally important is the legal probity of any proposed sale. A library must assure its clear title, unencumbered by restrictions that prevent sale or other disposition. If retention of legally restricted material is clearly in conflict with your institutional purposes, you may consider and pursue cy pres proceedings to change the legal restrictions. The New York Public Library did just this in the 1940s in order to transfer to the New-York Historical Society and the American Museum of Natural History collections of paintings and seashells from the Stuart Collection. One provision of the Stuart bequest, that materials in the collection not be exhibited on the Lord's Day, was removed by the cy pres proceedings for the collections transferred but remain in effect for the book collections, including many Bibles, which we retained.

Apart from legal restrictions, it is both a matter of good conscience and of good policy to honor, as far as resources permit, the intentions and wishes of the donor's gift or bequest. Even where sales are legal and desirable, the library should assure that resulting revenues be used in conformity with the donor's original intentions.

The library should also ascertain to the best of its ability the uniqueness, rarity or scarcity of materials being considered for disposal and assess the possible effects of dispersal on the access of the scholar or a more general public to the material. If an accession, by definition, makes something accessible, we should remember that a deaccession may make that item inaccessible. This is a particular problem with archival collections where a decision to discard is often irrevocable and the material is lost forever, though 
usually no proceeds are involved. ${ }^{15}$

Enough has been said already about duplicates, except to add that redundancy within the collection considerably enhances the case for disposal. Equally important is the relationship of the given item to the library's collecting policy, whether in scope or out of scope. Any responsible library will have the scope of its collecting policy under constant review. It is also certain to have many materials that are clearly out of scope, though there will always be arguments on the fringes, usually along the line that anything is grist for the social historian's mill, e.g., the current vogue of ephemera. At the New York Public Library, for example, we have such materials as paintings, stamps, coins, seashells (on loan), commemorative medals, and other three-dimensional objects. Each category will need a separate assessment to determine the probity of disposal (e.g., our stamp collection is both world famous and tied up by clear legal restrictions).

Having passed these various tests, we must next speculate on the net value of the possible sale, the potential yield less the real costs of deaccessioning (identification, processing, and legal), as well as the potential appreciation of the asset if retained as an investment. Perhaps the market can never be accurately anticipated, but a most painful example of the latter point was the sale by the New York Public Library, in 1956, of ten paintings, mostly from the Lenox Library, including two Turners, two Reynolds, a Constable, a Gainsborough, a Vernier, and a few others for $\$ 150,000$. One of the Turners was the first to come to this country, and its acquisition for Mr. Lenox was recounted at some length by. Henry Stevens in his Recollections of James Lenox. ${ }^{16}$ The sale of those paintings was a gamble that seems now to have been a bad one.

Another question concerns the responsibilities of an institution to maintain collections that are clearly identified with it. Should a library dispose of items which, sometimes flatteringly and sometimes pejoratively, are referred to as the crown jewels or treasures, which might bring a great price but are considered to carry an obligation with them to preserve and display? The New York Public Library has any number of such items, ranging from the manuscript of Washington's
Farewell Address to the Library Lions.

On a more mundane level but also important is the effect of removal on the so-called integrity of bibliographical records. Computer records of recent years can easily be updated to reflect changed holdings but book catalogs distributed throughout the world (including the pre-1956 National Union Catalog) will suggest the presence of works long since departed. Should that fact affect the institutional deaccession policy?

Is there exhibition potential in the item, which might be used for aesthetic, educational, or promotional purposes related to the primary purposes of the institution?

What effect might the present condition of the item have on a decision to remove? Should a library acquire and possess materials that it cannot preserve in good condition? Would it not be better to place the material in the hands of those who care enough about the item to pay for it?

Are there factors of space availability, peculiar processing requirements, or unusual security needs that would influence the decision one way or another?

What will be the public relations implications of the sale of specific library holdings?

What importance should be placed on unique bindings or association copies?

Most of these questions must be addressed on a case-by-case basis and the answers will vary dramatically. I have left the most difficult question to the end because the answer will depend not so much on individual cases but on perceived patterns of institutional behavior. I refer, of course, to the effects of deaccessioning on prospective donors and benefactors. This is a difficult question, fraught with imponderables, including exaggerated threats of the unlikely. Let me provide two examples of the problem.

The British Museum in its early years through 1830 was often plagued by the problem of duplicate disposal, partly from the pressure of Parliament to curtail the museum's space needs, partly from the alienation of potential gifts. The Quarterly Review for December 1850 , in a lengthy review of various reports on the state of the museum, included the following passage:

Nor was this all; the neglect shown, and the sale of duplicate books, disgusted many persons of sound and disposing mind, who, if 'things had been bet- 
ter managed, as in France,' would have bequeathed their stores to the national institution. To cherish what he has created, to desire to secure the intact preservation of these love-labours of his life, is natural to man; nor is the ambition to make a name - non omnis moriar-by making the public the heir to private treasures, an unpardonable or unpatriotic pride. Here this yearning has been chilled rather than fostered: can it be wondered that Lord Fitzwilliam (obit 1816), who intended to have bequeathed his collections to the Museum, should, on learning they were liable to be sold or lost, hand them over to the better taste and custody of Cambridge; or 'Northern Saxon' Gough, should select the Bodleian for the asylum of their precious accumulations? So Soane steered clear of the careless triton of Great Russell Street, in order to found his minnow Museum in Lincoln's Inn Fields; so Kirby the entomologist, fearful of 'basements,' took especial care that his beloved specimens should escape slow putrefaction and rapid cremation. ${ }^{17}$

Mr. Lenox himself in the 1840 s had made desirable exchanges with the museum through the efforts of Henry Stevens, including "the last enterprise of its kind which $\mathrm{Mr}$. Panizzi was permitted to effect. . . ."18 Perhaps the museum had enough problems of its own to be concerned with and needn't have begrudged Oxford and Cambridge their good fortune. The answers to the questions raised are truly speculative.

The second example is closer to home and equally speculative. On June 10, 1950, less than two weeks before his death, Dr. Albert A. Berg added the following codicil to his October 1949 last will and testament, which endowed his collection and other materials to the New York Public Library:

I make the provision in Paragraph marked "THIRTY-NINTH" of my said Last Will and Testament absolutely and unalterably conditioned upon the agreement by the Trustees of the New York Public Library not to sell, trade, exchange, barter, or in any manner whatsoever to transfer or allow to be transferred any books, manuscripts, papers, letters, illustrations, writings and art objects now in the Collection heretofore referred to, or which at any time may be added to said Collection. And I further provide that if at any time during the continuation of the trust herein provided the Trustees of the New York Public Library shall sell, trade, exchange, barter, or in any manner whatsoever transfer or allow to be transferred any books, manuscripts, papers, letters, illustrations, writings and art objects in the Collection hereinbefore referred to, then the bequest made in Para- graph marked "THIRTY-NINTH" of my said Last Will and Testament for the use and purposes therein set forth shall be revoked and the entire principal of said trust fund shall be forfeited by the Trustees of the New York Public Library and become the sole and exclusive property of the University of Pennsylvania, situated at Philadelphia, Pennsylvania, for the establishment of a library of valued old books, manuscripts, papers, writings and objects of art to be known forever as the BERG COLLECTION in memory of Henry W. and Albert A. Berg.

What happened to cause Dr. Berg's deathbed resolve to create such a restrictive legacy after many years of dealing with the library? It is doubtful if the full story could ever be reconstructed, but we do know that on February 8,1950 , Dr. Berg attended a meeting of the Board of Trustees of the New York Public Library at which the following resolution was approved:

Approval of the sale of "A Description of the Villa of Horace Walpole"

Upon recommendation from the Library Committee, and on motion duly made and seconded, the Board voted to authorize the sale from the Spencer Collection of "A Description of the Villa of Horace Walpole," with notes in Walpole's hand, for $\$ 2,000$ to Mr. Wilmarth Lewis whose Walpole Collection will be bequeathed to Yale University. ${ }^{19}$

No votes were recorded but oral tradition claims that Dr. Berg was silent throughout the discussion.

There is no doubt that the transfer was an honorable one, made with good intentions on both sides. Yet I cannot help but be reminded of an epithet of my eponymous benefactor, Andrew W. Mellon, to the effect that "no good deed goes unpunished." We can only speculate that Dr. Berg, horrified at the sale of a unique item from another endowed collection, did his best to protect his own name and collection. As a result, the Berg Collection, which might otherwise have sold its duplicates, now contains a splendid collection of literary duplicates, among them two Tamerlanes, two of Browning's Pauline, two of Bryant's Embargo, three Kilmarnock Burns', six or seven Pickwick Papers in parts, four of Bronte's Poems, nine copies of The Scarlet Letter, eleven of The House of Seven Gables, and five presentation copies of Thoreau's $A$ Week on the Concord and Merrimack Rivers - those presented to W. C. Bry- 
ant, Ellery Channing, R. W. Emerson, James A. Froude, and Nathaniel Hawthorne ${ }^{20}$ With that level of duplication, one can only imagine what the library's $\$ 2,000$ deaccession cost the Berg Collection and the library in potential support for growth in other areas of the Berg Collection.

I will pass over completely the question of the appropriate methods of sale or disposition and conclude with a few policy guidelines needed to control a responsible deaccession program. The board of trustees have recently approved tentative guidelines for the New York Public Library; they may be useful to other institutions facing the same questions and needs.

First, all proceeds from sales will be placed in restricted endowments, the income of which will be used for the strengthening or preserving of the collections.

Second, in general, inferior or lesser copies of duplicates should be the copies sold. Careful examination should determine true duplication.

Third, the library, will scrupulously honor the conditions under which gifts or bequests were accepted.

Fourth, the board of trustees is responsible to assure the best possible return on the sale of its assets.

Fifth, in general, manuscripts and association copies should be retained.

Sixth, emphasis in sales should be placed on out-of-scope and unrelated materials.

Seventh, the library will make full public disclosure in advance of its intended transactions. ${ }^{21}$

Those are the seven commandments we are now living with. Perhaps others can add three more to complete a Deaccessioning Decalogue.

\section{REFERENCES}

1. Patricia Failing, "George \& Martha \& Kevin \& Pandora," ARTnews 78:55 (Summer 1979); John Rewald, "Should Hoving Be DeAccessioned?" Art in America 61:25-30 (1973); and John Hess, The Grand Acquisitors (Boston: Houghton, 1974).

2. Ernst Robert Curtius, "The Book as Symbol," in W. R. Trask, trans., European Literature and the Latin Middle Ages (New York: Harper, 1963), p.302-47; Jon Thiem, "The Great Library of Alexandria Burnt: Toward the History of a Symbol," JHI 40:507-26 (Oct. 1979). See also Jorge Luis Borges, "The Cult of the Book," in Other Inquisitions 1937-1952 (Austin: Univ. of Texas Pr., 1964), p.116-20.

3. Sir Thomas Browne, Religio Medici, in Geoffrey Keynes, ed., Selected Writings (Chicago: Univ. of Chicago Pr., 1968), p.31.

4. George Bernard Shaw, Caesar and Cleopatra, in Three Plays for Puritans (New York: Brentano's, 1921), p.132-33.

5. Paget Toynbee and Leonard Whibley, eds. Correspondence of Thomas Gray, (Oxford: Clarendon, 1935), p.632-33.

6. Wilmarth Lewis, Collector's Progress (New York: Knopf, 1951), p. 252.

7. See Lord Byron's attack on Lord Elgin for his plundering of Greece by bringing the Elgin marbles to England: “And, last of all, amidst the gaping crew, / Some calm spectator, as he takes his view, / In silent indignation, mix'd with grief, I Admires the plunder but abhors the thief." The Curse of Minerva. The con- trary argument, often used, is that Lord Elgin's acquisition, for which he paid dearly, was essentially an act. of preservation. See Henry F. Taylor, The Taste of Angels (Boston: Little, Brown, 1948), p.497-508.

8. Falconer Madan, "The Duplicity of Duplicates" and "A New Extension of Bibliography," Transactions of the Bibliographical Society 12:15-24 (1914). Madan also quotes an 1887 letter from Edward Peacock: "My experience tallies with yours as to duplicates. I . . . have never found two alike, and yet simpletons keep saying in Parliament and elsewhere that the great libraries should turn out their duplicates and give them to the new libraries in the provinces. I wish someone who understands Bibliography would reply to this nonsense at length."

9. Fredson Bowers, Bibliography \& Modern Librarianship (Berkeley: Univ. of California Pr., 1966), p.21-22. For an argument in support of Bower's position from the perspective of the private collector, see G. Thomas Tanselle, "Non Firsts," in Jean Peters, ed., Collectible Books: Some New Paths (New York: Bowker, 1979), p.1-31.

10. Sir Thomas Bodley, Letters of Sir Thomas Bodley to Thomas James, G. W. Wheeler, ed. (Oxford: Clarendon Pr., 1926), p.35; passim.

11. Gabriel Naudé, Advice on Establishing a Library (Berkeley: Univ. of California Pr., 1950), p.77. 
12. Robert H. Taylor, "Bibliothecohimatiourgomachia," PBSA 48:230-38 (1954). Reprinted in The Bibliographical Society of America, 1904-79: A Retrospective Collection (Charlottesville: Univ. Pr. of Virginia, 1980), p.318-26.

13. On the art of transforming the ugly duckling into the swan, see Edwin Wolf II, "Fine Art of Selling Duplicates," Bookman's Yearbook (1968), p.3-5. See also J. M. Edelstein, "On Disposal of Duplicates," Ibid, p.6-7.

14. H. P. Kraus, A Rare Book Saga (New York: Putnam, 1978), p.88.

15. Leonard Rapport, "No Grandfather Clause: Reappraising Accessioned Records," Prologue 15:49-55 (Spring 1981).

16. Henry Stevens, Recollections of James Lenox (New York: New York Public Library, 1951), chapter 6 .

17. Quarterly Review 88:142 (Dec. 1850). See also Edward Miller, That Noble Cabinet (Athens, Ohio: Ohio Univ. Pr., 1974), p.71; passim. Also Arundell Esdaile, The British Museum
Library: A Short History and Survey (London: Allen \& Unwin, 1946), appendix 4.

18. Stevens, Recollections, p.60-64.

19. New York Public Library, "Board of Trustees Minute Book," 1950, p. 26.

20. These figures are taken from articles in the Bibliographical Society of America retrospective volume cited above, including John D. Gordan's "A Doctor's Benefaction: The Berg Collection at the New York Public Library," PBSA 48:303-14 (1954); there are many others. Robert Taylor's view that "after a careful examination has proved the extra [Berg] copies to be identical, it would be equally foolish to keep them," will have to be taken cum grano salis.

21. For a museum approach to these questions, see New York State Association of Museums, Guidelines, "The Ethics and Responsibilities of Museums with Respect to the Acquisition and Disposition of Collection Materials" (April 1974). 